Review Article

www.ijrap.net

\title{
CATHARANTHUS ROSEUS: A MEDICINAL PLANT WITH POTENT ANTI-TUMOR PROPERTIES
}

Punia Sandeep ${ }^{1}$, Kaur Jagjit ${ }^{1}$, Kumar Raman ${ }^{2}$ and Kumar Kuldeep ${ }^{3 *}$

${ }^{1}$ Research Fellow, Department of Biotechnology, M. M. University, Mullana, Haryana, India

${ }^{2}$ Assistant Professor, Department of Biotechnology, M. M. University, Mullana, Haryana, India

${ }^{3}$ Assistant Professor, Department of Biotechnology, M.M. Modi College, Patiala, Punjab, India

Received on: 11/09/14 Revised on: 01/10/14 Accepted on: 04/10/14

\author{
*Corresponding author \\ Dr. Kuldeep Kumar, Head, Department of Biotechnology, M.M. Modi College, Patiala-147001 Punjab, India \\ E-mail: kuldeepbio@gmail.com
}

DOI: $10.7897 / 2277-4343.056133$

\section{ABSTRACT}

Ayurveda is the Indian traditional system of medicine which focuses on the medical potential of plants. Catharanthus roseus is one plant recognized well in Ayurveda. It is known for its anti-tumour, anti-diabetic, anti-microbial, anti-oxidant and anti-mutagenic effects. It is an evergreen plant first originated from islands of Madagascar. The flowers may vary in colour from pink to purple and leaves are arranged in opposite pairs. It produces nearly 130 alkaloids mainly ajmalcine, vinceine, resperine, vincristine, vinblastine and raubasin. Vincristine and vinblastine are used for the treatment of various types of cancer such as Hodgkin's disease, breast cancer, skin cancer and lymphoblastic leukemia. It is an endangered species and need to be conserved using techniques like micro propagation. It has high medicinal values which need to be explored extensively.

Keywords: Alkaloids, Catharanthus roseus, vinblastine, vincristine, anti-cancer.

\section{INTRODUCTION}

The importance of medicinal plants has been renowned since 2600 BC in Mesopotamia ${ }^{1}$. World Health Organization (WHO) have prepared a list of 21000 medicinally important plants. One such plant is Catharanthus roseus (L.) G. Don which is also known as sadabahar or Periwinkle. The other names for $C$. roseus are Old-maid, Cape periwinkle, Vinca rosea, Rosy periwinkle, Rose periwinkle, Ammocallis rosea and Lochnera rosea ${ }^{2}$. It belongs to family Apocynaceae and is a rich source of alkaloids. These alkaloids are the secondary metabolites of plants which differ in their chemical structure. These are used for the various purposes such as pharmaceuticals, food additives; dye etc. $^{3}$ Being cultivated for hundreds of year C. roseus is an evergreen, perennial sub shrub with a height of $30 \mathrm{~cm}$ to 1 $\mathrm{m}$. It is known to be originated from island of Madagascar due to which it is also known as Madagascar periwinkle. But now it is found in most of the warm places of the world. It is also considered to be annual as it has the capabilities to tolerate high temperatures, drought conditions as well as heavy rainfall. The flower consist of five petal lobes which form a corolla of 2-5 cm diameter and these are white to pink-purple in colour. The centre is dark red in colour and the basal tube is $2.5-3 \mathrm{~cm} \mathrm{long}^{4}$. It possesses fruits which are follicle pairs of about $2-4 \mathrm{~cm}$ in length and $3 \mathrm{~mm}$ in breadth. The fruit is many seeded and the seeds are small, black, oblong or cylindrical ${ }^{4,5}$. The leaves are 1-3 inches long and arranged in opposite pairs. They may be oval, oblong or elliptic with pale midrib and rounded apex. These are glossy, dark green and hairless with a short petiole ${ }^{2,6}$. These plants are mostly found in warm places but they have also adapted to cold conditions. It can grow in different types of soils such as slightly acidic or soils with high moisture content and in low to full sunlight ${ }^{7}$. Different alkaloid are produced by different parts of this plant such as roots and basal stems produce reserpine, vinceine, raubasin and ajmalcine whereas antineoplastin dimeric vinblastine and vincristine are produced by aerial parts ${ }^{8}$ (Table 1). Maximum amount of these alkaloids is present in the root barks which rounds to nearly $0.15-1.34 \%$ and even $1.79 \%$ in some strains ${ }^{9}$. Out of the 130 different alkaloids produced by this plant 25 are dimeric in nature. Two such main examples of dimeric alkaloids are vinblastine and vincristine which are produced by aerial parts and used for the treatment of human neoplasma. Ajmalicine is a monomeric alkaloid produced by roots and used to treat circulatory diseases. Similarly other different alkaloids are used for many diseases such as lymphoblastic leukemia, Hodgkin's disease, skin cancer, breast cancer $4,10-12$ and Reticulum cell sarcoma, neuroblastoma, Wilkin's disease, diabetes, sore mouth, mouth ulcers, etc. These alkaloids are in great demand due to their medicinal importance and India is the third largest producer of vinblastine and vincristine. The production of these alkaloids depends on the developmental stage and physiological stage of the plant and these are obtained mostly from wild plants. Techniques such as tissue culture technique, media optimization and control of $\mathrm{pH}$, temperature, light aeration, phytohormones, etc. are being employed to increase their productivity. These techniques have various advantages such as dimeric alkaloids can be produced in large quantity which reduces their cost, even the slow growing plants can be used ${ }^{13}$ and different alkaloids can be produced in various quantities by bioengineering plants ${ }^{14-16}$. C. roseus has been used since long times for the treatment of various diseases in different parts of the world. It was used as diuretic, astringent and to treat cough in China and wasp stings in India ${ }^{17}$, nose bleed, sore throat, mouth ulcers and bleeding gums. It was used to get relief from lung congestion and inflammation in Central and South Asia, in Europe to treat diabetes $^{18}$. It also had some superstitious aspects with it such as in Europe people believed that it could help to get rid of evil spirits and it was called "violet of the sorcerers" 
by the French. Then the Western researchers found that the plant produces a number of alkaloids which has the medicinal values such as vindoline, catharanthine, lochnerine, vindolinine and leurosine sulphate lowers blood sugar levels, reserpine and serpentine are powerful tranquilizers and vincristine, vinblastine have anticancerous properties. Alkaloids are the nitrogen containing compounds produced by the plant which are usually bitter in taste and they possess anticancer and pain relieving properties. Vincristine and vinblastine are produced by the leaves ${ }^{19,20}$ whereas vindoline is mainly produced by the green parts of the plant ${ }^{21}$ and catharanthine by the roots. Out of the various alkaloids produced by this plant more than 100 are monoterpenoid indole alkaloids (MIAs) which have anticancer properties $^{22}$. Enzymatic and non-enzymatic antioxidants are also produced by this plant ${ }^{23,24}$. Wound healing, hypoglycaemic, analgesic and vasodilatory effects are some of the other medicinal applications of C. roseus ${ }^{25}$. High blood pressure and cardio-vascular diseases can be treated using ajmalicine and serpentine which are found in the roots. A large amount of phytochemical compounds are present in the leaves and stem of this plant which makes it plant of medicinal value. Its conservation is the point of concern as it comes under the endangered species $^{7}$.

Table 1: Different Alkaloids Produced By Catharanthus roseus

\begin{tabular}{|c|c|c|}
\hline Produced by & Alkaloids & Properties \\
\hline \multirow{4}{*}{ Roots } & Ajmalicine & Cardio-Vascular Diseases And High Blood Pressure \\
\cline { 2 - 3 } & Catharathine & Anti-Diabetic Properties \\
\cline { 2 - 3 } & Raubasin & Pain Relieving Properties \\
\cline { 2 - 3 } & Reserpine & Tranquilizers \\
\cline { 2 - 3 } & Serpentine & Cardio-Vascular Diseases And High Blood Pressure \\
\hline Aerial parts like leaves & Vinblastine & Anti-Tumour Properties \\
\cline { 2 - 3 } & Vincristine & Anti-Tumour Properties \\
\cline { 2 - 3 } & Vindoline & Anti-Diabetic Properties \\
\hline
\end{tabular}

\section{Medicinal Properties of Catharanthus roseus Anti-Cancerous Effect}

C. roseus produces vinblastine and vincristine which are well known for their anti-cancerous properties. ${ }^{26}$ ElMerzabani et al., 1979 injected ethanol (70\%) extract of leaves intra peritoneally to female mice. As a result the alkaloids showed great responses against different types of cancers especially those that are multi-drug resistant. The nineteen patients suffering from plantar, genital, flat or Verruca vulgaris warts were cured. When the chloroform extract was injected to the patients suffering from Leuk-P3887 then only one was resistant to the treatment, five showed $50 \%$ response and six were completely treated $^{27}$. Both the malignant and nonmalignant, platelet and platelet-associated disorders are effectively treated using the $C$. roseus alkaloids ${ }^{28}$. In recent studies it has been found that growth of blood vessels that enhance tumour growth is inhibited by alkaloids secreted by $C$. roseus ${ }^{29}$. These alkaloids, vincristine and vinblastine are used as injectable anticancer drugs ${ }^{30}$ such as vinblastine as Velban and vincristine as Oncovin ${ }^{7}$. The division of cancer cells is interfered by these drugs along with their derivatives such as vinflunine. Vincristine is used in the treatment of leukemia in children and vinblastine for choriocarcinoma and Hodgkin's disease ${ }^{7}$.

\section{Anti-Microbial Effect}

A number of anti-microbial agents have been used to prevent the adverse effects caused by various microbes. It is very important to discover new antimicrobial agents ${ }^{31}$ because the rate of antibiotic production is much lower than the rate at which the microbes are becoming resistant to them ${ }^{32}$. The plant extracts are useful in attaining the long term health response and also reducing the ill effects of various chemotherapeutic agents ${ }^{33}$. Plants like $C$. roseus provide a broad spectrum of resistance against microbial agents and can be used as a prophylactic agent in the treatment of number of diseases. It has proved to possess efficient anti-viral ${ }^{34}$, anti-bacterial ${ }^{35}$ and antifungal $^{36}$ compound. Tobacco Mosaic Virus (TMV) was inhibited by water extract of callus culture of micro propagated plant $^{37}$. Bacillus megatarium and Staphylococcus albusi did not grow on agar plates with 70 $\%$ ethanol extract of dried leaves but $B$. cereus and $S$. aureus were resistant to same extract ${ }^{38}$. Proteus, Staphylococcus, Shigella and Pseudomonas species are inhibited by the benzene extract of dried flowers (50\%) whereas the same concentration of benzene extract of dried leaves inhibited Salmonella species in addition to the above mentioned bacterial species ${ }^{39}$. Antifungal effect was shown using different plant part extracts and each of them was active against different fungi. Trichophyton mentagrophytes was inhibited by hot water extract of both leaves and stem ${ }^{40,41}$. There was no effect on Neurospora crossa by the acetone and water extract $(70 \%)$ of aerial parts of plant ${ }^{42}$. A study by ${ }^{43}$ Khalil, 2012 has shown the antimicrobial activity of $C$. roseus against bacteria $(S$. aureus and E. coli) and fungus (Candida albicans). The antibacterial activity of $C$. roseus was also shown by ${ }^{44}$ Govindasamy and Srinivasan in 2012 in which they studied the effects of extracts from leaf, stem, root, and flower against a number of bacteria. The maximum antibacterial activity was shown against $S$. typhi and minimum against $S$. aureus and $E$. coli. The antimicrobial activity of $C$. roseus was studied against $B$. fusiformis, $C$. albicans, E. coli and Aspergillus fumigatus using agar well disc diffusion assay and paper disc diffusion assay. The methanolic extract of stem was active against $B$. fusiformis, leaves against $A$. fumigates and flowers against B. fusiformis ${ }^{45}$. The crude extract from different parts of this plant was used to study the antibacterial activity against Salmonella typhimuruimi (NCIM2501), S. aureus (NCIM5021) and Pseudomonas aeruginosa (NCIM2036). The results showed that it was a potent antibacterial agent $^{7}$. Stem extracts of $C$. roseus were used to save 
rubber trees (Hevea brasiliensis) from White rot disease caused by Rigidoporus microporus named fungus. It was found that the extract proved to be an efficient healing agent for the infected trees ${ }^{46}$.

\section{Anti-Mutagenic and Anti-Mitotic Effect}

The anti-mitotic effect was shown by administrating the female mice with ethanol $(70 \%)$ extract of dried leaves which showed positive results on CA-Fhrlich ascites vs. induction of metaphase arrest in ascites cells ${ }^{47}$. In a study conducted by ${ }^{48}$ Sharma et al., 1982 it was found that when the red blood cells (RBCs) were subjected to hot water extract of dried leaves the number of micro-nucleated polychromatic RBCs decreased which proved the antimutagenic effect of $C$. roseus. The mutagenic effect of vincristine, an alkaloid secreted by $C$. roseus was studied using sex linked recessive lethal (SLRL) test system in Drosophilla melanogaster. The results thus obtained showed that vincristine produced many chromosomal effects, arrest cells at metaphase with highly contracted chromosomes and inhibition of tubulin polymerization ${ }^{49}$. When the root tips of $C$. roseus were treated with ethylmetahne sulphonate (EMS) then a number of chromosomal anomalies were observed such as persistent nucleolus, condensation, fragmentation, laggered, bridge, cleft and binucleolated cells ${ }^{50}$.

\section{Anti-Oxidant Effect}

Tannins, phenolics and flavonoids are the anti-oxidants produced by medicinal plants which are more potent than the anti-oxidants secreted by dietary plants ${ }^{51}$. Reactive oxygen species (ROS) are the harmful compounds that our body generates during normal aerobic respiration and anti-oxidants are helpful in eradicating these compounds $^{52}$. C. roseus is known to produce many different alkaloids such as flavonol glycosides, caffeoylquinic acids, etc. ${ }^{53-55}$ Phenolic compounds are the products of secondary metabolism of plants and act as anti-oxidants, anti-inflammatory, anti-microbial, cardioprotective and anti-allergic agents. Their anti-oxidant potential is because they are efficient hydrogen donors, reducing agents, metal chelators or singlet oxygen quencher ${ }^{56-58}$. When a number of medicinal plants were screened for their oxygen radical absorbance capacity (ORAC) it was found that $C$. roseus has the highest ORAC value i.e. $22.30 \mu \mathrm{mol}$ Trolox equivalent (TE)/g of fresh weight $^{59}$. C. roseus has also been shown to scavenge the nitric oxide, superoxide and DPPH (1,1-diphenyl-2picrylhydrazyl) radicals ${ }^{54}$. In 2011 Rasool $^{60}$ and his collogues demonstrated through their research that $C$. roseus is a viable source of natural antioxidants which can be exploited for food and nutraceutical applications. The anti-oxidant activity of $C$. roseus was studied in different regions of Rajasthan and it was found that plants of Bikaner region had highest phenolic content followed by Kota and Jaipur, India ${ }^{61}$. C. roseus is free of side effects and cost effective and efficient means to get rid from oxidative stress mediated diseases. The antioxidant effect of $C$. roseus (pink flowers) and C. alba (white flowers) was checked and it was found that $C$. roseus has higher antioxidant activity than C. alba $a^{7}$.

\section{Anti-Diabetic Effect}

Diabetes, malaria, dementia, etc. can also be treated by using the different extracts of this plant. Vinca rosea has the ability to improve the blood supply to brain which results in increased supply of oxygen and glucose to brain and also preventing the abnormal coagulation of blood. $V$. rosea also helps in increasing the levels of serotonin whose deficiency may cause diseases like migraine, bulimia, phobias and schizophrenia. This plant helps in increasing the insulin production and utilization of sugar from food which helps in curing diabetes. An alkaloid named alstonine which is mainly present in its root bark helps in regulating the blood pressure. In a case study in Malaysia the diabetes patients who took decoctions of this plant in combination with regular medications showed better response as compared to those who undergone only oral medications and insulin ${ }^{62,63}$. Maximum of the reported work about anti-diabetic potential of this plant is being conducted using the crude extract rather than the pure bioactive compounds ${ }^{64-67}$. In streptozotocin induced diabetic rat this plant induces hypoglycemic effect ${ }^{68,69}$. From this plant four alkaloids: vindolie I, II, III and IV were extracted which enabled high glucose uptake in pancreatic $\beta$-TC6 or myoblast $\mathrm{C} 2 \mathrm{C} 12$ cells and elicited their use against type 2 diabetes $^{70}$. The alkaloid vincamine helps in the treatment of vascular dementia, a disease caused by the plaque development of arteries carrying blood to brain. Vincamine also causes blood thinning and helps to enhance the memory properties ${ }^{2}$. C. roseus lowers the blood sugar levels in a dose dependent manner ${ }^{7}$. The anti-diabetic potential of $C$. roseus was evaluated by studying the protein content in its different parts with highest content in half mature leaves ${ }^{71}$.

\section{CONCLUSION}

Catharanthus roseus is one of the 21000 important medicinal plants found. It is used for the cure of a number of diseases such as diabetes, sore mouth, mouth ulcers, and leukemia. It produces about 130 alkaloids such as reserpine, vinceine, raubasin and ajmalcine. Antileukemic activity is shown by vinblastine and vincristine. Different parts of this plant produce different amounts of alkaloids, out of which root bark produces the maximum i.e. nearly $1.79 \%$. There are a number of reports supporting its anti-microbial activity against Staphylococcus albusi, Bacillus megatarium, Shigella, Pseudomonas, etc. Its anti-oxidant and anti-mutagenic effects have also been reported. Further studies need to be done to explore its anti-tumour effects.

\section{REFERENCES}

1. Koehn FE and Carter GT. The evolving role of natural products in drug discovery. Nat Rev Drug Discover 2005; 4: 206-20. http://dx.doi.org/10.1038/nrd1657

2. Gayatri CL, Chakravarthy R. Micro Propagation in Catharanthus roseus. Internat J Innov Tech Exploring Eng (IJITEE) 2013; 2(5).

3. Taha HS, El Bahr MK and Seif El Nasr MM. In vitro studies on Egyptian Catharanthus roseus (L.). II. Effect of biotic and abiotic stress on indole alkaloids -production. J Appl Sci Res 2009; 5: 1826-31.

4. Cononer RA and Litz RE. In vitro propagation of Catharanthus roseus. Hort Sci 1978; 13: 241-42.

5. Devis DR. Cell and tissue culture potential for Catharanthus roseus plant breeding. Phil Tran R Soc. (London) 1981; 292: 547-56. 
6. Rajora RK, Sharma NK and Sharma V. Effect of plant growth regulators on micro propagation of Catharanthus roseus. Internat $\mathrm{J}$ Adva Biotechnol Res 2013; 4(1): 123-30.

7. Sain M and Sharma V. Catharanthus roseus (An anti-cancerous drug yielding plant) - A Review of Potential Therapeutic Properties. Int J Pure App Biosci 2013; 1(6): 139-142.

8. Singh R, Kharb P and Rani K. Rapid Micro propagation and Callus Induction of Catharanthus roseus in Vitro Using Different Explants. World J Agri Sci 2011; 7(6): 699-704.

9. Singh VP, Jagdev RSD. Ajmalicine (raubacine); A medicinally important alkaloid from Catharanthus roseus (Vinca rosea). In supplement: Cultivation and utilization of medicinal plants. Handa SS and Kaul MK (eds) RRL, Jammu; p. 199-206.

10. El Sayed A and Cordell GA. Catharanthamine, a new antitumor bisindole alkaloid from Catharanthus roseus. J Nat Prod 1981; 11: 289-93. http://dx.doi.org/10.1021/np50015a009

11. Matkowski A. Plant in vitro culture for the production of antioxidants- A review. Biotechnol Advan 2008; 26: 548-60. http://dx.doi.org/10.1016/j.biotechadv.2008.07.001

12. Gomes F, Simoes M, Lopes ML and Canhoto JM. Regulators and genotype on the micro propagation of adult trees of Arbutus unedo L. (strawberry tree). New Biotechnol 2010; 27(6): 882-92. http://dx.doi.org/10.1016/j.nbt.2010.02.009

13. Zhao R and Verpoorte R. Manipulating indole alkaloid production by Catharanthus roseus cell cultures in bioreactors: from biochemical processing to metabolic engineering. Phytochem Rev 2007; 6: 435-57. http://dx.doi.org/10.1007/s11101-006-9050-0

14. Moreno PRH, Van Der Heijden R and Verpoorte R. Cell and tissue cultures of Catharanthus roseus: A literature survey. Plant Cell Tissue Org Cult 1995; 42: 1-25. http://dx.doi.org/ 10.1007/BF00037677

15. Stern S. Introductory Plant Biology. $8^{\text {th }}$ ed. McGraw- Hill Companies Inc; 2000. p. 238-47.

16. Gragg GM and Newman DJ. Plants as a source of anti- cancer agents. J Ethnopharmacol 2005; 100: 72-9. http://dx.doi.org/ 10.1016/j.jep.2005.05.011

17. Farnsworth NR. The pharmacognosy of the periwinkles: Vinca and Catharanthus. Lloydia 1961; 24(3): 105-38.

18. Swanston Flatt CK, Day C, Flatt PR, Gould BJ and Bailey CJ. Glycaemia effects of traditional European plant treatments for diabetes studies in normal and streptozotocin diabetic mice. Diabetes Res 1989; 10(2): 69-73.

19. Svoboda GH and Blake DA. The phytochemistry and pharmacology of Catharanthus roseus (L) G. Don. In: Taylor WI, Farnsworth NR, eds. The catharanthus alkaloids. New York, NY: Marcel Dekker; 1975. p. 4583 .

20. Neuss N. The spectrum of biological activities of indole alkaloids. In: Phillipson JD, Zenk MH eds. Indole and biogenetically related alkaloids. London: Academic Press; 1980. p. 293-313.

21. De Luca V, Balsevich J, Tyler RT, Eilert U, Panchuk BD and Kurz WGW. Biosynthesis of indole alkaloids: developmental regulation of the biosynthetic pathway from tabersonine to vindoline in Catharanthus roseus. J Plant Physiol 1986; 125: 147-56. http://dx.doi.org/10.1016/S0176-1617(86)80252-8

22. Magnotta M, Murata J, Chen J, De Luca V. Identification of a low vindoline accumulating cultivar of Catharanthus roseus (L.) G Don by alkaloid and enzymatic profiling. Phytochem 2006; 67: 1758-64. http://dx.doi.org/10.1016/j.phytochem.2006.05.018

23. Jaleel CA, Gopi R, Alagulakshmanan GM and Panneerselvam R. Triadimefon induced changes in the antioxidant metabolism and ajmalicine production in Catharanthus roseus (L.) G. Don. Plant Sci 2006; 171: 271-76. http://dx.doi.org/10.1016/j.plantsci.2006.03.018

24. Jaleel CA and Panneerselvam R. Variations in the anti oxidative and indole alkaloid status in different parts of two varieties of Catharanthus roseus, an important folk herb. Chinese J Pharmacol and Toxicol 2007; 21: 487-94.

25. Nayak BS and Lexley MPP. Catharanthus roseus flower has wound healing activity in Sprague Dawley rats. BMC Complimentary Alternat Med 2006; 6: 41. http://dx.doi.org/10.1186/1472-6882-6-41

26. El Merzabani MM, El Aaser AA, Attia MA, El Duweini AK, Ghazal AM. Screening system for Egyptian plants with potential antitumour activity. Planta Med 1979; 36: 150-55. http://dx.doi.org/10.1055/s-0028-1097255

27. Chattopadhyay SP and Das PK. Evaluation of Vinca rosea for the treatment of warts. Indian J Dermatol Venerol Leprol 1990; 56(2): $107-08$.
28. The Wealth of India. Raw Materials (Revised Edition), Vol. 3, C.S Ambusta (Editor in Chief), Publication and Information Directorate, CSIR, New Delhi; 1992.

29. Zhang LB, Gou LH and Zeng SV. Preliminary study on the isolation of endophytic fungus of Catharanthus roseus and its fermentation to produce product of therapeutic value. Chinese Traditional Herbal Drugs 2000; 11: 805-07.

30. Duflos A, Kruczynski A and Barret JM. Novel aspects of natural and modified vinca alkaloids. Curr Med Chem Anti Cancer Agents 2002; 2: 55-70. http://dx.doi.org/10.2174/1568011023354452

31. Gootz TD. Discovery and development of new antimicrobial agents. Clin Microbiol Rev 1991; 2: 176-81.

32. Russell AD. Antibiotic and biocide resistance in bacteria: Introduction. J Appl Microbial Symp Supply 2002; 2: 176-81.

33. Kaushik P and Dhiman AK. Medicinal Plants and Raw Drugs of India; 2002. p. XII +623 .

34. Farnsworth NR, Svoboda GH and Blomster RN. Antiviral activity of selected Catharanthus alkaloids. J Pharmacol Sci 1968; 57: 217475. http://dx.doi.org/10.1002/jps.2600571235

35. Carew DP and Patterson BD. The effect of antibiotics on the growth of Catharanthus roseus tissue cultures. Lloydia 1970; 33: 275-77.

36. Jaleel CA, Manivannan P and Sankar B. Induction of drought stress tolerance by ketoconazole in Catharanthus roseus is mediated by enhanced antioxidant potentials and secondary metabolite accumulation. Colloids and surf. B, Biointerfaces 2007; 60: 20-206. http://dx.doi.org/10.1016/j.colsurfb.2007.06.010

37. Misawa M. Production of natural substances by plant cell cultures described in Japanese patents. Plant Tissue Culture its Bio-Technol Appl Int Cong; 1976. p. 17-26.

38. Ross SA, Megalla SE, Bishay DW and Awad AH. Studies for determining antibiotic substances in some Egyption Plants. Part 1. Screening for antimicrobial activity. Fitoterapia 1980; 51: 303-08.

39. Rajas MCN and Cuellar MCA. Comparative microbiological studies of the alkaloids of Catharanthus roseus and other related compounds. Rev Cubana Farm 1988; 15(2): 131-38.

40. Chile SK, Saraf M, Barde AK. Efficacy of Vinca rosea extract against human pathogenic strains of Trichophyton rubrum Sab. Indian Drugs Pharm Ind 1981; 16(1): 31-33.

41. Rai MK, Upadhyay S. Screening of medicinal plants of Chhindwara district against Trichophyton mentagrophytes: A casual organism of Tineapedis. Hindustan Antibiot Bull. 1988; 30(1/2): 33-36.

42. Kubas J. Investigation on known or potential anti tumour plants by means of microbiological test. Part III. Biological activity of some cultivated plant species in Neurospora crassa test. Acta Biol Cracov Ser Bot 1972; 15: 87-100.

43. Khalil A. Antimicrobial Activity of Ethanol Leaf Extracts of Catharanthus Roseus from Saudi Arabia 2012; 48: 6-11.

44. Govindasamy $\mathrm{C}$ and Srinivasan R. In vitro antibacterial activity and phytochemical analysis of Catharanthus roseus (Linn.) G. Don. Asian Pacific J Tropical Biomed 2012; S155-S158.

45. Kumari K and Gupta S. Phytopotential of Catharanthus Roseus L. (G.) Don. Var. Rosea and Alba against Various Pathogenic Microbes In Vitro 2013; 3(3): 77-82.

46. Zaini HM and Halimoon N. Stems Extract of Kemuning cina (Catharanthus roseus) as Bio fungicides against White Root Fungal (Rigidoporus microporus) of Rubber Trees (Hevea brasiliensis). J Biofertil Biopestici 2013; 4(2): 1-4.

47. El Merzabani MM, El Aaser AA, El Duweini AK, El Masry AM. A Bioassay of anti mitotic alkaloids of Catharanthus roseus. Planta Med 1979; 36: 87-90. http://dx.doi.org/10.1055/s-0028-1097246

48. Sharma OP, Makkar HPS and Dawra RK. Biochemical effects of the plant Lantana camara in guinea pig liver mitochondria. Toxicon 1982; 20: 783-86. http://dx.doi.org/10.1016/0041-0101(82)90125-8

49. Ahmed ES, Twaty NH, Fakiha KG and Bibars MA. Mutageneic and anti mutagenic effects of some plant extracts in Drosophilla melanogaster. Nature and Sci 2010; 8(4): 77-82.

50. Verma AK, Singh RR and Singh S. Cytogenetic effect of EMS on root meristem cells of Catharanthus roseus (L.) G. Don var. Nirmal. International Journal of pharma and bio sciences 2012; 2(1): 20-24.

51. Ghimire BK, Seong ES, Kim EM, Ghimeray AK, Yu CY, Ghimireand BK et al. A comparative evaluation of the antioxidant activity of some medicinal plants popularly used in Nepal. J Med Plants Res 2011; 51: 884-91.

52. Salah N, Miller NJ, Paganga G, Tijburg L, Bolwell GP and Rice Evans C. Poly phenolic flavanols as scavengers of aqueous phase radicals and as chain-breaking antioxidants. Arch Biochem Biophy 1995; 322: 339-46. http://dx.doi.org/10.1006/abbi.1995.1473 
53. Mustafa RN and Verpoorte R. Phenolic compounds in Catharanthus roseus. Phytochem Rev 2007; 6: 3243-58. http://dx.doi.org/10.1007 /s11101-006-9039-8

54. Ferreres F, Pereira DM, Valentão P, Andrade PB, Seabra RM and Sottomayor M. New phenolic compounds and antioxidant potential of Catharanthus roseus. J Agric Food Chem 2008; 56: 9967-74. http://dx.doi.org/10.1021/jf8022723

55. Ferreres F, Figueiredo R, Bettencourt S, Carqueijeiro I, Oliveira J, Gil Izquierdo A, et al. Identification of phenolic compounds in isolated vacuoles of the medicinal plant Catharanthus roseus and their interaction with vacuolar class III peroxidase: an $\mathrm{H}_{2} \mathrm{O}_{2}$ affair? J Exp Botany 2011; 62: 2841-54. http://dx.doi.org/10.1093 /jxb/erq458

56. Strube M, Dragstedt LO and Larsen JC. Naturally Occurring Anti tumour gens. Plant Phenols. The Nordic Council of Ministers, Copenhagen; 1993. p. 39-40.

57. Kahkonen MP, Hopia AI, Vuorela HJ, Rauha JP, Pihlaja K and Kujala TS. Antioxidant activity of plant extracts containing phenolic compounds. J Food Chem 1999; 47: 3954-62. http://dx.doi.org/ $10.1021 / \mathrm{jf} 9901461$

58. Balasundram N, Sundram K and Sammar S. Phenolic compounds in plants and agri industrial by-products: Antioxidant activity, Occurrence, and potential uses. J Food Chem 2006; 68: 191-203. http://dx.doi.org/10.1016/j.foodchem.2005.07.042

59. Zheng $\mathrm{W}$ and Wang SY. Antioxidant activity and phenolic compounds in selected herbs. J Agric Food Chem 2001; 49: 5165 70. http://dx.doi.org/10.1021/jf010697n

60. Rasool N, Rizwan K, Zubair M, Naveed KR, Imran I and Ahmed VU. Antioxidant potential of different extracts and fractions of Catharanthus roseus shoots. Internat J Phytomed 2011; 3: 108-14.

61. Kumar A, Singhal KC, Sharma RA, Vyas GK and Kumar V. Analysis of Antioxidant Activity of Catharanthus Roseus L. and it's Association with Habitat Temperature. Asian J Exp Biol Sci 2012; 3(4): 706-13.

62. Letchuman GR, Wan Nazaimoon WM, Wan Mohamad WB, Chandran LR, Tee GH, Jamaiyah H, et al. Prevalence of diabetes in the Malaysian national health morbidity survey III 2006. Med J Malays 2010; 65: 173-79.

63. Kevin LYW, Hussin AH, Zhari I, and Chin JH. Sub-acute oral toxicity study of methanol leaves extract of Catharanthus roseus in rats. J Acute Dis 2012; 1: 38-41. http://dx.doi.org/10.1016/S22216189(13)60009-8

64. Nammi S, Boini MK, Lodagala SD and Behara RB. The juice of fresh leaves of Catharanthus roseus Linn. reduces blood glucose in normal and alloxan diabetic rabbits. BMC Complement Altern Med 2003; 3: e2. http://dx.doi.org/10.1186/1472-6882-3-2

65. Ohadoma SC and Michael HU. Effects of co-administration of methanol leaf extract of Catharanthus roseus on the hypoglycemic activity of metformin and glibenclamide in rats. Asian Pac J Trop Med 2011; 4: 475:77.

66. Gacche RN and Dhole NA. Profile of aldose reductase inhibition, anti-cataract and free radical scavenging activity of selected medicinal plants: An attempt to standardize the botanicals for amelioration of diabetes complications. Food Chem Toxicol 2011; 49: 1806-13. http://dx.doi.org/10.1016/j.fct.2011.04.032

67. Ganga RM, Satyanarayana S and Eswar KK. Safety of Gliclazide with the aqueous extract of Vinca rosea on pharmacodynamic activity in normal and alloxan induced diabetic rats. J Pharm Res 2012; 5: 1555-58.

68. Chattopadhyay RR. A comparative evaluation of some blood sugar lowering agents of plant origin. J Ethnopharmacol 1999; 67: $367-$ 72. http://dx.doi.org/10.1016/S0378-8741(99)00095-1

69. Singh SF, Vats P, Suri S, Shyam R, Kumria MM, Ranganathan S, et al. Effect of an antidiabetic extract of Catharanthus roseus on enzymic activities in streptozotocin induced diabetic rats. J Ethnopharmacol 2001; 76: 269-77. http://dx.doi.org/10.1016/S03788741(01)00254-9

70. Tiong SH, Looi CY, Hazni H, Arya A, Paydar M, Wong WF, et al. Antidiabetic and Antioxidant Properties of Alkaloids from Catharanthus roseus (L.) G. Don. Molecules 2013; 18: 9770-84. http://dx.doi.org/10.3390/molecules18089770

71. Aparajita J, Chauhan UK, Singh AK, Kumar D and Praveen N. Pharmacological evaluation for the presence of protein in the leaves of Catharanthous roseous. Pharma Sci Monitor 2014; 5(2): 50-52.

\section{Cite this article as:}

Punia Sandeep, Kaur Jagjit, Kumar Raman and Kumar Kuldeep. Catharanthus roseus: A medicinal plant with potent Anti-tumor properties. Int. J. Res. Ayurveda Pharm. 2014;5(6):652-656 http://dx.doi.org/10.7897/2277-4343.056133 